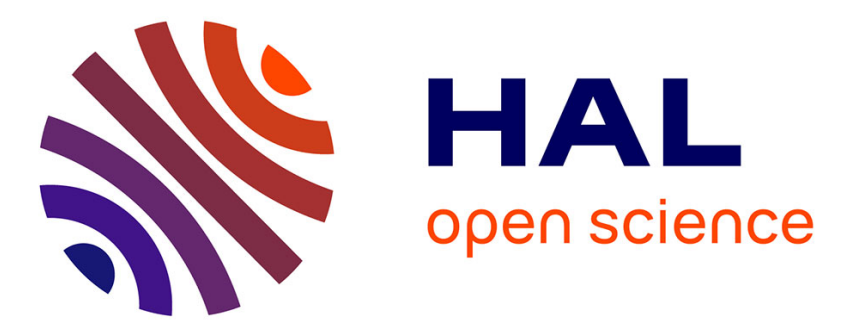

\title{
Metoclopramide stimulates catecholamine- and granin-derived peptide secretion from pheochromocytoma cells through activation of serotonin type 4 (5-HT4) receptors \\ Johann Guillemot, Patricia Compagnon, Dorthe Cartier, Erwan Thouennon, Christian Bastard, Isabelle Lihrmann, Perrine Pichon, Christian Thuillez, Pierre-François Plouin, Jérôme Bertherat, et al.
}

\section{- To cite this version:}

Johann Guillemot, Patricia Compagnon, Dorthe Cartier, Erwan Thouennon, Christian Bastard, et al.. Metoclopramide stimulates catecholamine- and granin-derived peptide secretion from pheochromocytoma cells through activation of serotonin type 4 (5-HT4) receptors. Endocrine-Related Cancer, 2008, 16 (1), pp.281 - 290. 10.1677/ERC-08-0190 . hal-01706408

\section{HAL Id: hal-01706408}

https://hal-normandie-univ.archives-ouvertes.fr/hal-01706408

Submitted on 18 Jul 2018

HAL is a multi-disciplinary open access archive for the deposit and dissemination of scientific research documents, whether they are published or not. The documents may come from teaching and research institutions in France or abroad, or from public or private research centers.
L'archive ouverte pluridisciplinaire HAL, est destinée au dépôt et à la diffusion de documents scientifiques de niveau recherche, publiés ou non, émanant des établissements d'enseignement et de recherche français ou étrangers, des laboratoires publics ou privés. 


\title{
Metoclopramide stimulates catecholamine- and granin-derived peptide secretion from pheochromocytoma cells through activation of serotonin type $4\left(5-\mathrm{HT}_{4}\right)$ receptors
}

\author{
Johann Guillemot ${ }^{1}$, Patricia Compagnon ${ }^{2}$, Dorthe Cartier ${ }^{1}$, Erwan Thouennon ${ }^{1}$, \\ Christian Bastard $^{3}$, Isabelle Lihrmann ${ }^{1}$, Perrine Pichon ${ }^{4}$, Christian Thuillez ${ }^{2}$, \\ Pierre-François Plouin ${ }^{5}$, Jérôme Bertherat ${ }^{6}$, Youssef Anouar ${ }^{1}$, Jean-Marc Kuhn ${ }^{4}$, \\ Laurent Yon ${ }^{1}$ and Hervé Lefebvre ${ }^{1,4}$

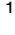 \\ INSERM U413, EA4310, DC2N, IFRMP 23, University of Rouen, Mont Saint Aignan, France \\ 2 INSERM U644, Department of Pharmacology, Institute of Biomedical Research, Rouen University Hospital, Rouen, France \\ 3 \\ Laboratory of Oncologic Genetics, Centre Henri Becquerel, Rouen, France \\ 4 Department of Endocrinology, Institute of Biomedical Research, Rouen University Hospital, Rouen, France \\ Hypertension Unit, Paris Descartes University, AP-HP, Hôpital Européen Georges Pompidou, Paris, France \\ 6 INSERM U567, Department of Endocrinology, Cochin Institute, CNRS UMR8104, Cochin Hospital, Paris Descartes University, \\ AP-HP, Paris, France
}

(Correspondence should be addressed to H Lefebvre, INSERM U413, IFRMP 23, Department of Endocrinology, Hospital of $\mathrm{CHU}$ of Rouen, 76031 Rouen Cedex, France; Email: herve.lefebvre@chu-rouen.fr)

\section{Introduction}

The worldwide used gastroprokinetic and antiemetic agent metoclopramide is known to exert stimulatory effects on prolactin and aldosterone secretions in human subjects (Norbiato et al. 1977, Harrington et al. 1983).
These two endocrine actions are usually attributed to the antidopaminergic properties of the compound (Fraser 1987, Molitch 1992). Metoclopramide has also been shown to induce acute hypertensive crisis and adrenergic myocarditis in patients with pheochromocytoma and 
metoclopramide administration has been used as a provocative test in the diagnosis of pheochromocytoma (Plouin et al. 1976, Agabiti-Rosei et al. 1977, Sever 1977, Abe et al. 1984, Hsu et al. 1993, Maxwell et al. 2001, Leow \& Loh 2005). In some cases, metoclopramideinduced adrenergic myocarditis presented as a dilated cardiomyopathy with profound left ventricular akinesia (Maxwell et al. 2001, Leow \& Loh 2005). The mechanism of metoclopramide-evoked hypertensive crisis in these patients likely involves an increase in norepinephrine release via presynaptic $\mathrm{D}_{2}$ receptor blockade, an inhibition of the vasodilatory effect of dopamine leading to potentiation of the hypertensive action of norepinephrine and epinephrine, and a direct stimulatory effect of the drug on pheochromocytoma cells (Plouin et al. 1976, Abe et al. 1984, Adler-Graschinsky et al. 1984). Although the occurrence of dopamine $\mathrm{D}_{2}$ receptors has been clearly established in pheochromocytoma tissues (Wu et al. 2001), the molecular events involved in the action of metoclopramide on pheochromocytoma cells are not fully elucidated.

Beside its antagonistic action at $\mathrm{D}_{2}$ receptors, metoclopramide is able to act as a partial agonist at the serotonin4 $\left(5-\mathrm{HT}_{4}\right)$ receptor type (Dumuis et al. 1989). The 5-HT receptor is a 7-transmembrane domain receptor positively coupled to adenylyl cyclase (Bockaert et al. 2004, Brattelid et al. 2004). Its primary transcript is alternatively spliced to produce nine receptor isoforms that differ in the length and structure of their C-terminal tail (a-g, i, and n) and one variant that exhibits a 14-amino acid insertion within the second extracellular loop (h; Bockaert et al. 2004, Brattelid et al. 2004). It is now recognized that the 5 - $\mathrm{HT}_{4}$ receptor mediates metoclopramide-evoked aldosterone secretion as well as the abnormal response of plasma cortisol to metoclopramide observed in some patients with ACTH-independent macronodular adrenal hyperplasia (Lefebvre et al. 1993, Rizzi et al. 1997, Cartier et al. 2003, Christopoulos et al. 2005).

In the present report, a pheochromocytoma removed from a patient who experienced hypertension crisis after metoclopramide administration was used as a model for the study of the mechanism of action of metoclopramide on pheochromocytoma cells. In vitro experiments were conducted in order to examine the effect of metoclopramide on the secretion of catecholamine- and granin-derived peptides, including the secretogranin II-derived peptide EM66 and the chromogranin A-derived peptide WE14, by cultured pheochromocytoma cells. In addition, RT-PCR analysis was used to investigate the expression of $5-H T_{4}$ receptor mRNA in the patient's tumor and a retrospective series of 17 pheochromocytomas.

\section{Methods}

\section{Patients and materials}

A 46-year-old woman was referred to our Department of Endocrinology for a recently discovered left adrenal tumor measuring $7 \mathrm{~cm}$ of diameter. She had a history of labile hypertension and paroxysmal spells of headache, palpitations, and cold sweating, and was therefore highly suspected of pheochromocytoma. Immediately after admission, she complained of nausea and unfortunately received $10 \mathrm{mg}$ metoclopramide orally. Thirty minutes later, her blood pressure and pulse rose to $180 / 100 \mathrm{mmHg}$ and $150 / \mathrm{min}$ respectively, and signs of cardiac insufficiency appeared. She was then transferred to the cardiological intensive care unit. Ventriculography showed profound hypokinesia and a large thrombus of the left ventricle. Treatment with low-molecular-weight heparin, aspirin, and prazosin led to recovery of normal ventricular function, regression of the ventricular thrombus, and normalization of blood pressure allowing surgical removal of the adrenal mass. Pathological examination of the tumor confirmed the diagnosis of pheochromocytoma. All clinical signs of catecholamine excess completely resolved after surgery.

Fragments of the tumor were obtained at surgery and either immediately transported to the laboratory for culture experiments or frozen on dry ice and stored at $-80{ }^{\circ} \mathrm{C}$ until RT-PCR experiments. RT-PCR studies were also performed in a retrospective series of 17 pheochromocytomas (nine benign and eight malignant) provided by a French endocrinological network for collection of adrenal tumors (Réseau COMETE) and stored at $-80{ }^{\circ} \mathrm{C}$ until utilization. The tumors (mean diameter $64 \pm 25 \mathrm{~mm}$, range $30-120 \mathrm{~mm}$ ) had been obtained from eight women and nine men (mean age $47.6 \pm 16.5$ year, range $13-68$ year). Five tumors were of extra-adrenal localization. The diagnosis of benign tumor was assessed on the absence of any histological criteria of malignancy, mutation in the succinate dehydrogenase B $(S D H B)$ gene, and tumor recurrence or metastatic diffusion during a follow-up of at least 2 years. Malignancy was established by the presence of at least one metastasis. Normal adrenomedullary tissue explants (control tissues) were obtained from two brain-dead organ donors. The adrenal medulla was carefully dissected from the cortex with a scalpel by scraping off the brown interdigited islets of chromaffin cells, as described previously (Cavadas et al. 2001). This method allows obtaining a degree of purity of 95\% for chromaffin cells when the tissues are used for cell culture experiments. The protocols of collection of the tissues and the experimental procedures were 
approved by the regional ethics committee and informed consent was obtained from all patients with pheochromocytoma.

\section{Primary culture of pheochromocytoma cells}

Pheochromocytoma fragments were immersed in culture medium (DMEM; Sigma-Aldrich), transported to the laboratory, and processed as described previously (Guillemot et al.2006). Briefly, the tissues were minced with scissors, and tumor cells were enzymatically dispersed in DMEM containing $0.1 \%$ collagenase (Serlabo, Bonneuil-sur-Marne, France) and $30 \mathrm{U} / \mathrm{ml}$ DNase I (Sigma-Aldrich). Isolated cells were cultured in DMEM supplemented with $5 \%$ calf serum (Biowhittaker Europe, Verviers, Belgium), 10\% horse serum (Invitrogen), $100 \mathrm{U} / \mathrm{ml}$ penicillin, $100 \mu \mathrm{g} / \mathrm{ml}$ streptomycin, and $0.25 \mu \mathrm{g} / \mathrm{ml}$ fungizone (Life Technologies). Tumoral chromaffin cells were purified by overnight differential plating to remove adherent non-chromaffin cells and then plated at a density of $10^{6}$ cells/ml per well. After 1 day, pheochromocytes were treated with metoclopramide (Sigma-Aldrich), dopamine (Sigma-Aldrich), cisapride $\left(10^{-7} \mathrm{M}\right.$; Laboratoire Janssen, Boulogne-Billancourt, France), domperidone (Sigma-Aldrich), and/or the 5- $\mathrm{HT}_{4}$ receptor antagonist GR $113808\left(10^{-7} \mathrm{M}\right.$; GlaxoSmithKline, Greenford, England, UK). The cells were incubated with each secretagogue (three wells for each concentration tested) for $24 \mathrm{~h}$ at $37^{\circ} \mathrm{C}$. The culture medium was then collected and immediately frozen at $-80{ }^{\circ} \mathrm{C}$ until HPLC or at $-20^{\circ} \mathrm{C}$ until RIA.

\section{Catecholamine- and granin-derived peptide assays}

Characterization and quantitation of norepinephrine and epinephrine in cell culture medium were carried out by HPLC combined with electrochemical detection after extraction on alumina, using a method adapted from that previously used for the measurement of plasma catecholamine concentrations (Joannides et al. 1998).

The concentrations of EM66 and WE14 were measured by RIA. Purified recombinant EM66 and synthetic [Tyr0] WE14 were iodinated by the chloramine-T method and separated from free iodine on SepPak C18 cartridges using a gradient of acetonitrile $(0-100 \%)$ in $0.1 \%$ trifluoroacetic acid (TFA), as described previously (Montero-Hadjadje et al. 2002, Guillemot et al. 2006). The RIA was performed in veronal buffer ( $\mathrm{pH} 7.4$ ) supplemented with $0.4 \%$ BSA (BSA; Roche Diagnostics) and $0.1 \%$ Triton X-100. The EM66 and WE14 antisera, used at a final dilution of
1:60 000 and 1:100 800 respectively, were incubated with 7000 c.p.m. tracer/tube in the presence of graded concentrations of standard (purified EM66 or synthetic WE14) or culture medium. After 2-day incubation at $4{ }^{\circ} \mathrm{C}$, the antibody-bound fraction was immunoprecipitated by the addition of $100 \mu \mathrm{l}$ of $20 \%$ bovine $\beta$-globulins and $1 \mathrm{ml}$ of $5 \%$ polyethylene glycol 8000 . After 20-min incubation at room temperature, the mixture was centrifuged $\left(5000 \mathrm{~g}, 30 \mathrm{~min}, 4{ }^{\circ} \mathrm{C}\right)$ and the pellet containing the bound fraction was counted on a $\gamma$-counter (LKB, Wallack, Rockville, MD). The standard curve was set up with concentrations of EM66 or WE14 ranging from 5 to $10000 \mathrm{pg} /$ tube.

\section{RNA extraction and real-time RT-PCR}

Total RNA from the 18 pheochromocytomas including the patient's tumor and two normal adrenal medulla was extracted by the acid guanidium thiocyanatephenol-chloroform procedure by using TRI reagent (Sigma). The concentration of total RNA was determined by measuring the optical density at $260 \mathrm{~nm}$. Real-time RT-PCR analysis was carried out as described by Fink et al. (1998) in order to quantify $5-\mathrm{HT}_{4}$ receptor mRNA in both pheochromocytomas and normal adrenal medulla. The primers and fluorogenic TaqMan probe used for these experiments hybridized to all 5- $\mathrm{HT}_{4}$ receptor splice variants as previously published (Cartier et al. 2005). Briefly, $1 \mu \mathrm{g}$ total RNA from each tissue was converted to singlestranded cDNA using SuperScript II from Life Technologies with oligo (dT) $12-18$ primer $(0.5 \mu \mathrm{g} / \mathrm{ml})$, and the cDNA was diluted and aliquoted into microtitre plates. For each 25- $\mu$ l TaqMan reaction, $5 \mu \mathrm{l}$ cDNA was mixed with $1 \mu \mathrm{l}$ water, $12.5 \mu \mathrm{l}$ TaqMan Universal PCR Master Mix 2× (Applied Biosystems, Courtaboeuf, France), $2 \mu \mathrm{l}$ sense primer $(2 \mu \mathrm{M}), 2 \mu \mathrm{l}$ antisense primer $(2 \mu \mathrm{M})$, and $2.5 \mu \mathrm{l}$ TaqMan probe $(2 \mu \mathrm{M})$. PCR parameters were $50{ }^{\circ} \mathrm{C}$ for $2 \mathrm{~min}, 95^{\circ} \mathrm{C}$ for $10 \mathrm{~min}, 40$ cycles of $95^{\circ} \mathrm{C}$ for $15 \mathrm{~s}$, and $60{ }^{\circ} \mathrm{C}$ for $1 \mathrm{~min}$. Parallel assays using the same cDNA pools were carried out using primers and probe to the housekeeping gene porphobilinogen deaminase. Quantitative RT-PCR was performed using an ABI Prism 7700 sequence detector system (Applied Biosystems) and analyzed using relative expression to porphobilinogen deaminase (PBGD), as previously described (Cartier et al. 2005). Briefly, the level of expression in each sample was normalized by dividing copies/ng total RNA of $5-H T_{4}$ receptor gene by copies/ng total RNA of porphobilinogen deaminase gene, and expressed as a percentage. This mode of calculation allows correcting for both RNA quality and quantity. 


\section{Characterization of $5-\mathrm{HT}_{4}$ receptor isoforms by RT-PCR}

Total RNA was extracted and reverse transcribed as described above. Amplification of the cDNAs encoding the different $5-\mathrm{HT}_{4}$ receptor $\mathrm{C}$-terminal splice variants was performed by $\mathrm{PCR}$ using primer $\mathrm{S} 1$, which hybridizes to all 5- $\mathrm{HT}_{4}$ receptor messengers, and splice variant-specific reverse primers as previously published (Cartier et al. 2005). The 5-HT $4(\mathrm{~h})$ variant was amplified using the forward primer Fwh, which is specific for cDNAs containing the $5-\mathrm{HT}_{4(\mathrm{~h})}$ exon, and the reverse primer Revh, which hybridizes to all 5-HT $\mathrm{HT}_{4}$ receptor messengers. All PCR-based procedures were performed in a final volume of $50 \mu \mathrm{l}$ containing $10 \%$ reverse transcription mixture, $3 \mathrm{U}$ DNA Taq Polymerase (Life Technologies), DNA Polymerase buffer (Life Technologies), $1.5 \mathrm{mM}$ $\mathrm{MgCl}_{2}, 0.4 \mathrm{mM} \mathrm{dNTP}$, and $20 \mathrm{pmol}$ of each primer. The PCRs were performed for 40 cycles $\left(94{ }^{\circ} \mathrm{C}, 40 \mathrm{~s}\right.$; $50{ }^{\circ} \mathrm{C}, 60 \mathrm{~s} ; 72{ }^{\circ} \mathrm{C}, 90 \mathrm{~s}$ ). The PCR products were analyzed in $1.5 \%$ agarose gels, blotted on a nylon membrane, and hybridized with the [32P]ATP-labeled oligonucleotide S2. In addition, PCR products were subcloned into pGEM-T (Promega) and sequenced, using the Thermosequenase kit (Amersham) on a Li-Cor 4200L DNA sequencer (ScienceTec, Les Ulis, France) using fluorescent T7 and T3 primers (MWGBiotech, Courtaboeuf, France).
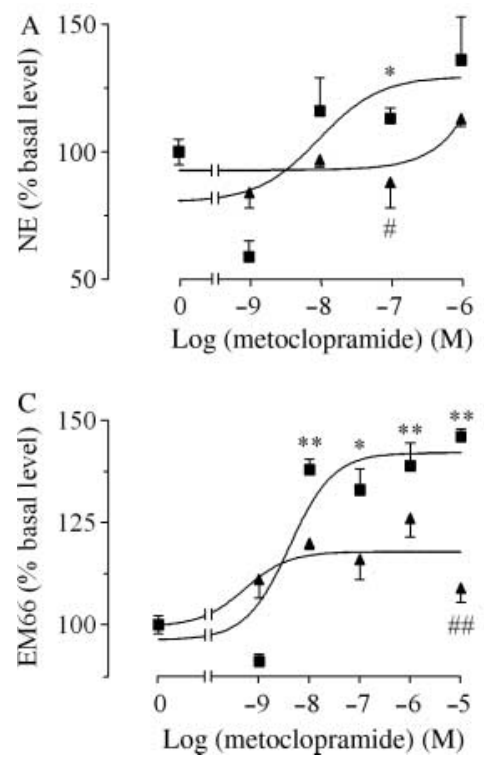

\section{Statistical analysis}

All results of cell incubation studies were expressed as mean \pm s.E.M., and statistical analysis was performed using Dunnett's test after one-way ANOVA. Potencies and efficacies of the test substances are expressed as concentrations that produced half-maximum responses $\left(\mathrm{EC}_{50}\right)$ and maximum stimulations $\left(E_{\max }\right)$ respectively. Expression levels of $5-H T_{4}$ mRNAs in the benign and malignant pheochromocytomas were compared using the Mann-Whitney $U$-test. Probability values less than 0.05 were considered significant. Data were analyzed with the Prism program (GraphPad Software, San Diego, CA, USA).

\section{Results}

\section{Effect of metoclopramide on catecholamine- and granin-derived peptides from cultured pheochromocytoma cells}

Administration of graded concentrations of metoclopramide $\left(10^{-9}\right.$ to $\left.10^{-6} \mathrm{M}\right)$ to pheochromocytoma cells in primary culture induced a dose-dependent increase in norepinephrine and epinephrine secretion (Fig. 1A and B). The potencies $\left(\mathrm{EC}_{50}\right)$ and efficacies $\left(E_{\max }\right)$ of metoclopramide to stimulate catecholamine production were $1.44 \times 10^{-8} \mathrm{M}$ and $+44 \pm 12 \%$ respectively for norepinephrine, and $1.23 \times 10^{-8} \mathrm{M}$ and $+43 \pm 12 \%$ respectively for epinephrine. Interestingly, a concentration of
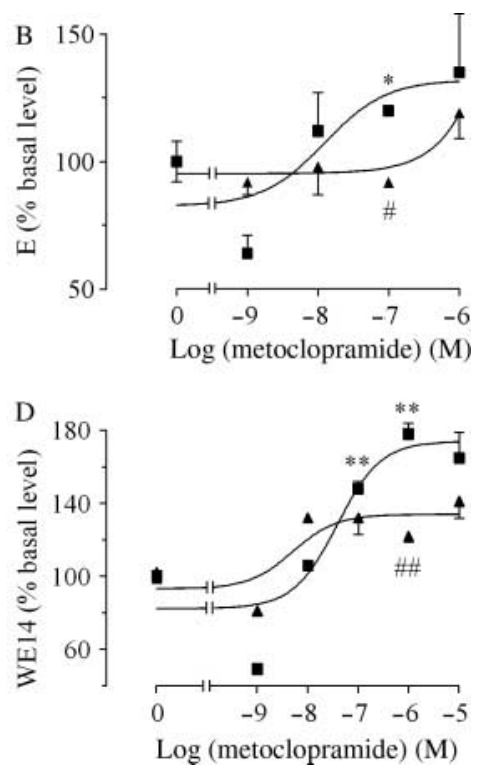

Figure 1 Effect of metoclopramide on (A) norepinephrine (NE), (B) epinephrine (E), (C) EM66, and (D) WE14 production from pheochromocytoma cells. Graded doses of metoclopramide $\left(10^{-9}\right.$ to $\left.10^{-5} \mathrm{M}\right)$ were incubated with cultured pheochromocytoma cells in the absence $(\boldsymbol{\square})$ or presence $(\boldsymbol{\Delta})$ of the $5-\mathrm{HT}_{4}$ receptor antagonist GR $113808\left(10^{-7} \mathrm{M}\right)$. Each point represents the mean of at least three determinations, expressed as percentages of basal level (control). Bars denote S.E.M. ${ }^{\star} P<0.05$ and ${ }^{\star \star} P<0.01$ versus control; $\# P<0.05$ and \#\#P<0.01 versus metoclopramide alone. 
$10^{-7} \mathrm{M}$ metoclopramide, which corresponds to the level of metoclopramide commonly observed in plasma after oral intake of $10 \mathrm{mg}$ of the drug (Lamparczyk et al. 2001), was sufficient to trigger a significant increase (i.e., $+20 \pm 4 \%$ for norepinephrine and $+23 \pm 4 \%$ for epinephrine) in catecholamine secretion. Metoclopramide also induced a concentration-dependent increase in EM66 and WE14 productions (Fig. $1 \mathrm{C}$ and D) with $\mathrm{EC}_{50}$ reaching respectively $4.03 \times 10^{-9}$ and $3.84 \times 10^{-8} \mathrm{M}$, and $E_{\max }$ of $+46 \pm 4 \%$ and $78 \pm 12 \%$ respectively. The norepinephrine, epinephrine, EM66, and WE14 responses to metoclopramide were all inhibited by GR 113808 $\left(10^{-7} \mathrm{M}\right)$, a $5-\mathrm{HT}_{4}$ receptor antagonist devoid of any dopaminergic properties (Grossman et al. 1993; Fig. 1).

\section{Effect of cisapride and domperidone on catecholamine- and granin-derived peptides from cultured pheochromocytoma cells}

Incubation of cultured pheochromocytoma cells with the $5-\mathrm{HT}_{4}$ receptor agonist cisapride at the concentration observed in plasma $\left(C_{\max }\right)$ after oral administration of the drug, i.e., $10^{-7} \mathrm{M}$ (Gross et al. 1999), induced a significant stimulation of norepinephrine $(+23 \pm 4 \%)$, epinephrine $(+24 \pm 1 \%)$, EM66 $(+43 \pm 3 \%)$, and WE14 $(+63 \pm 15 \%)$ production (Fig. 2). Cisapride-induced catecholamine- and granin-derived peptide secretions were inhibited by GR $113808\left(10^{-7} \mathrm{M}\right)$. In contrast to cisapride, domperidone $\left(10^{-6} \mathrm{M}\right)$, a dopaminergic $\mathrm{D}_{2}$ receptor antagonist devoid of any agonistic activity at the $5-\mathrm{HT}_{4}$ receptor, had no significant effect on catecholamine- and granin-derived peptide release (Fig. 2).

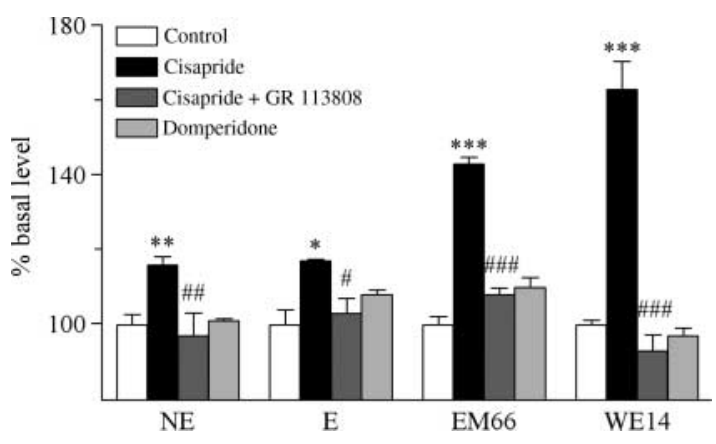

Figure 2 Effects of the $5-\mathrm{HT}_{4}$ receptor agonist cisapride and the dopamine $\mathrm{D}_{2}$ receptor agonist domperidone on norepinephrine (NE), epinephrine (E), EM66, and WE14 production from pheochromocytoma cells. Cisapride $\left(10^{-7} \mathrm{M}\right)$ was incubated with cultured pheochromocytoma cells in the absence (black bars) or presence (dark grey bars) of GR $113808\left(10^{-7} \mathrm{M}\right)$. Domperidone was incubated with pheochromocytoma cells at the concentration of $10^{-6} \mathrm{M}$ (light grey bars). Each point represents the mean of at least three determinations, expressed as percentages of basal level (control, open bars). Bars denote S.E.M. ${ }^{\star} P<0.05,{ }^{\star \star} P<0.01$, and ${ }^{* \star \star} P<0.001$ versus control; $\# P<0.05$, \#\#P<0.01, and\#\#\#P<0.001 versus cisapride alone.
Effect of metoclopramide on the catecholamineand granin-derived peptide responses to dopamine from cultured pheochromocytoma cells

Incubation of pheochromocytoma cells with graded concentrations of dopamine $\left(10^{-9}\right.$ to $\left.10^{-6} \mathrm{M}\right)$ induced a dose-dependent inhibition of catecholamine production reaching $-49 \pm 2 \%$ for norepinephrine and $-51 \pm 3 \%$ for epinephrine (Fig. 3A and B). Interestingly, the inhibitory effect of dopamine on norepinephrine and epinephrine secretions was not significantly influenced by metoclopramide $\left(10^{-6} \mathrm{M}\right.$; Fig. 3A and B). In contrast to its negative action on catecholamine release, dopamine dose dependently stimulated EM66 and WE14 production with maximum efficacies of $+28 \pm 10 \%$ and $+30 \pm 6 \%$ (Fig. $3 \mathrm{C}$ and D).

\section{Quantitative expression of $5-\mathrm{HT}_{4}$ receptors in normal adrenal medulla and pheochromocytomas}

We have investigated the quantitative expression of $5-H T_{4}$ receptor mRNA by the tissues by real-time PCR using oligonucleotides hybridizing to all receptor variants. $5-H T_{4}$ receptor mRNAs were detected in all the tissues (Fig. 4). When expressed as arbitrary units normalized to porphobilinogen deaminase, $5-\mathrm{HT}_{4}$ receptor expression levels were 3.61 and $1.23 \%$ in the two normal medulla explants, $0.13-207 \%$ with a median value of $2.01 \%$ in benign pheochromocytomas, and $0.28-25.4 \%$ with a median value of $2.22 \%$ in malignant pheochromocytomas. There was no significant difference in the expression rates of benign versus malignant pheochromocytomas. The patient's pheochromocytoma was one of the tissues that expressed the highest levels of $5-H T_{4}$ receptor mRNA, i.e., $29.7 \%$.

\section{Characterization of $5-\mathrm{HT}_{4}$ receptor isoforms by RT-PCR in normal adrenal medulla and pheochromocytomas}

RT-PCR amplification was applied to characterize $5-\mathrm{HT}_{4}$ receptor isoforms in both normal adrenal medulla and pheochromocytomas (Table 1). None of the known isoforms was detected in adrenomedullary explants. By contrast, pheochromocytoma tissues were found to frequently express isoforms (a), (b), (c), (i), and (n). Isoform ( $\mathrm{g}$ ) was present in two tumors, i.e., one benign (no. 3) and one malignant (no. 10). Two pheochromocytomas (nos. 6 and 17) exclusively expressed isoform (b). There was no significant difference between the profiles of expression of $5-\mathrm{HT}_{4}$ receptor isoforms in benign and malignant pheochromocytomas, respectively. 

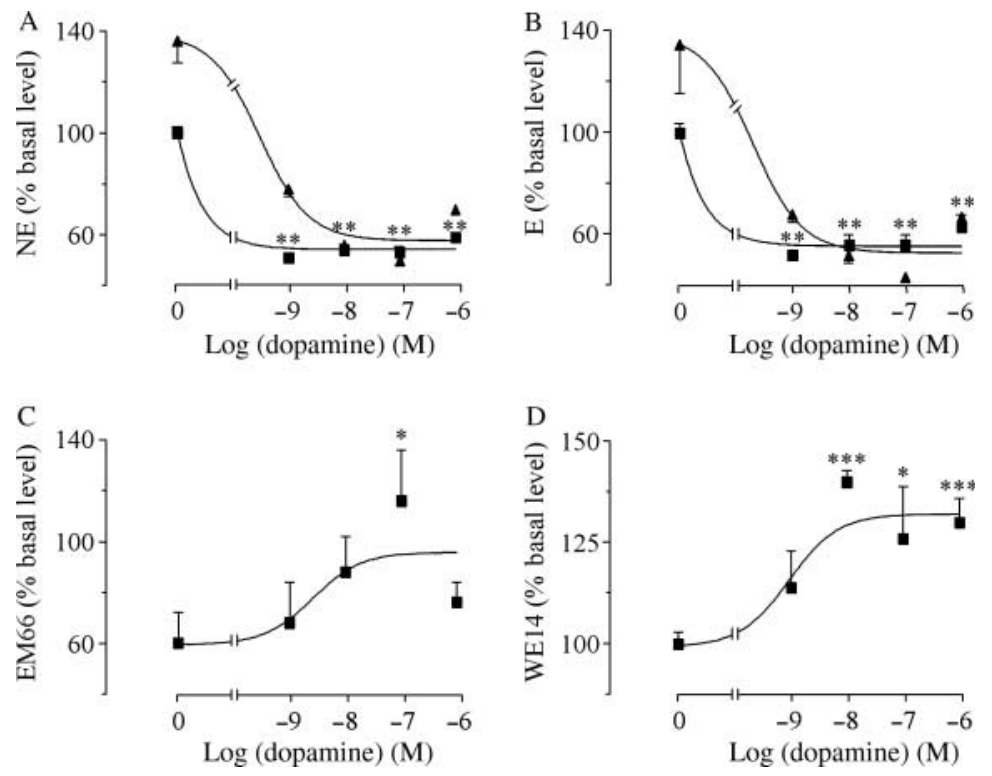

Figure 3 Effect of dopamine on (A) norepinephrine (NE), (B) epinephrine (E), (C) EM66, and (D) WE14 production from pheochromocytoma cells. Graded concentrations of dopamine $\left(10^{-9}\right.$ to $\left.10^{-6} \mathrm{M}\right)$ were incubated with cultured pheochromocytoma cells in the absence $(\boldsymbol{\square})$ or presence $(\boldsymbol{\Delta})$ of metoclopramide $\left(10^{-6} \mathrm{M}\right)$. Each point represents the mean of at least three determinations, expressed as percentages of basal level (control). Bars denote S.E.M. ${ }^{\star} P<0.05,{ }^{\star \star} P<0.01$, and ${ }^{\star \star \star} P<0.001$ versus control.

\section{Discussion}

In the present study, we have used pheochromocytoma tissue removed from a patient who experienced hypertension crisis and acute adrenergic myocarditis after metoclopramide administration, as an in vitro model for the study of the mechanism of action of metoclopramide on pheochromocytoma cells. It was indeed probable that metoclopramide may have triggered catecholamine secretion from the tumor tissue, leading to severe hypertensive paroxysm. Consistent with this hypothesis, our results showed that metoclopramide dose dependently stimulated catecholamine production from pheochromocytoma cells. It was also physiopathologically relevant to note that the concentration of metoclopramide usually observed in the plasma after oral intake of the drug $\left(10^{-7} \mathrm{M}\right)$ was sufficient to stimulate catecholamine release by tumor cells. Moreover, culture experiments showed that metoclopramide potently stimulated the production of two granin-derived peptide release, i.e., EM66 and WE14, that have previously been detected in pheochromocytoma tissues (Montero-Hadjadje et al. 2002, Yon et al. 2003, Guillemot et al. 2006).

The observation that metoclopramide-induced catecholamine- and granin-derived peptide productions were reduced by the specific $5-\mathrm{HT}_{4}$ antagonist GR 113808 indicates that the stimulatory effect of metoclopramide on pheochromocytes is at least partly mediated by $5-\mathrm{HT}_{4}$ receptors. The presence of functional $5-\mathrm{HT}_{4}$ receptors in the patient's pheochromocytoma tissue was confirmed by the following results: cisapride, another 5- $\mathrm{HT}_{4}$ receptor agonist devoid of any antidopaminergic properties, activated catecholamine, and granin-derived peptide secretion; the stimulatory effect of cisapride was completely inhibited by GR 113808 . As $\mathrm{D}_{2}$ receptors are expressed in pheochromocytoma tissues (Wu et al. 2001), it was conceivable that metoclopramide may have also activated tumor cells through its antagonistic $\mathrm{D}_{2}$

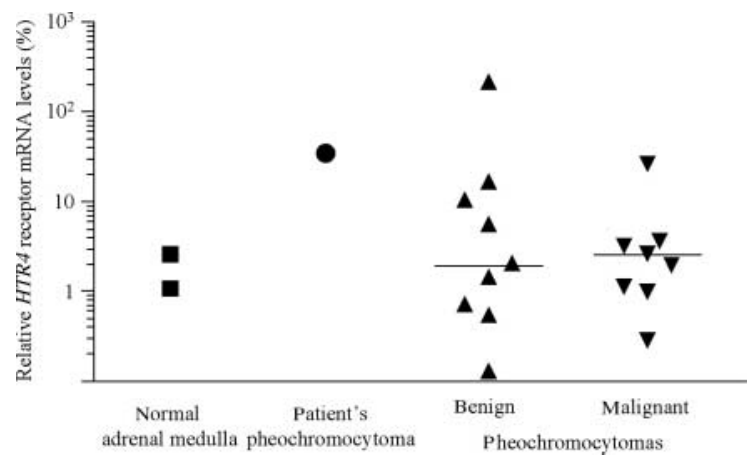

Figure 4 Expression of $5-\mathrm{HT}_{4}$ receptor mRNA in pheochromocytoma tissues. $5-\mathrm{HT}_{4}$ receptor mRNA level was quantified in normal adrenal medulla ( $\boldsymbol{\square})$, the patient's pheochromocytoma $(\boldsymbol{O})$, benign ( $\boldsymbol{\Delta})$, and malignant $(\boldsymbol{\nabla})$ pheochromocytomas by the use of real-time RT-PCR. The horizontal bars represent the median values observed in the groups of benign and malignant pheochromocytomas. The level of expression in each sample was normalized by dividing copies/ng total RNA of $5-H T_{4}$ receptor gene by copies/ng total RNA of porphobilinogen deaminase gene, and expressed as a percentage. 
Table 1 Expression of $5-\mathrm{HT}_{4}$ receptor isoforms in normal adrenal medulla and pheochromocytomas

\begin{tabular}{|c|c|c|c|c|c|c|c|c|c|c|}
\hline & $\mathbf{a}$ & b & C & d & e & $f$ & $\mathbf{g}$ & $\mathbf{h}$ & $\mathbf{i}$ & $n$ \\
\hline N1 & - & - & - & - & - & - & - & - & - & - \\
\hline $\mathrm{N} 2$ & - & - & - & - & - & - & - & - & - & - \\
\hline PP & - & + & + & - & - & - & - & - & + & + \\
\hline 1 & + & + & + & - & - & - & - & - & + & + \\
\hline 2 & + & + & + & - & - & - & - & - & + & + \\
\hline 3 & + & + & + & - & - & - & + & - & + & + \\
\hline 4 & + & + & + & - & - & - & - & - & + & + \\
\hline 5 & - & + & - & - & - & - & - & - & + & - \\
\hline 6 & - & + & - & - & - & - & - & - & - & - \\
\hline 7 & + & + & + & - & - & - & - & - & + & + \\
\hline 8 & + & + & + & - & - & - & - & - & + & + \\
\hline 9 & + & + & + & - & - & - & - & - & + & + \\
\hline 10 & + & + & + & - & - & - & + & - & + & + \\
\hline 11 & + & + & + & - & - & - & - & - & + & + \\
\hline 12 & + & + & + & - & - & - & - & - & + & + \\
\hline 13 & - & + & + & - & - & - & - & - & + & + \\
\hline 14 & + & + & + & - & - & - & - & - & + & + \\
\hline 15 & + & + & + & - & - & - & - & - & + & + \\
\hline 16 & + & + & + & - & - & - & - & - & + & + \\
\hline 17 & - & + & - & - & - & - & - & - & - & - \\
\hline
\end{tabular}

N1-2, normal adrenal medulla; PP, patient's pheochromocytoma; 1-9, benign pheochromocytomas; 10-17, malignant pheochromocytomas; +, expression; -, no detectable expression.

receptor properties. In fact, it is well documented that metoclopramide stimulates prolactin secretion by block-ing the inhibitory action of dopamine on pituitary lactotrophs (Molitch 1992). In agreement with this hypothesis, we noted that dopamine potently decreased norepinephrine and epinephrine release, as previously reported in sympathetic nerve terminals and adrenal medulla (Mannelli et al. 1995). However, metoclopra-mide had no action on dopamine-evoked inhibition of catecholamine release indicating that metoclopramide does not stimulate catecholamine production by antag-onizing the effect of dopamine on pheochromocytes. These results also suggest that the inhibitory action of dopamine on norepinephrine and epinephrine secretion is not mediated by $\mathrm{D}_{2}$ receptors. As the presence of $\mathrm{D}_{4}$ receptor in pheochromocytomas has been clearly established (Wu et al. 2001), it is possible that the dopaminergic regulation of catecholamine production by pheochromocytoma cells may involve this dopamine receptor type for which metoclopramide exhibits a low affinity (Rizzi et al. 1997). The observation that metoclopramide and dopamine effects on catecholamine release were independent of the $\mathrm{D}_{2}$ receptor was also consistent with the lack of significant action of domperidone, a well-known $\mathrm{D}_{2}$ receptor antagonist devoid of any serotonin antagonistic properties, on norepinephrine and epinephrine secretions by the patient's tumor cells. In contrast to its inhibitory effect on norepinephrine and epinephrine release, dopamine acted as a potent stimulator of granin-derived peptides production, indicating that metoclopramide could not activate granin secretion through its dopamine antagonistic properties. These data also show that dopamine can differentially regulate catecholamine- and graninderived peptide productions from pheochromocytoma cells. The processes involved in these complex regulations likely involve selective release of secretory granule contents through kiss-and-run and/or piecemeal degranulation (Crivellato et al. 2006).

The occurrence of functional $5-\mathrm{HT}_{4}$ receptors in the patient's pheochromocytoma led us to investigate quantitative and qualitative expressions of $5-H T_{4}$ receptor mRNAs in two normal adrenomedullary tissues and benign and malignant pheochromocytomas. Using primers hybridizing to the common region of all $5-\mathrm{HT}_{4}$ receptor isoforms, we observed the presence of $5-H T_{4}$ receptor mRNAs in all tissues studied, including the patient's tumor, which was one of the tissues that expressed the highest levels of the receptor. There were no statistically significant differences between the expression levels of benign versus malignant pheochromocytomas. The fact that normal adrenomedullary explants expressed $5-H T_{4}$ receptor mRNA at levels similar to those observed in pheochromocytoma tissues was unexpected with regard to the observation that the potency of metoclopramide to stimulate catecholamine secretion in vivo and to elevate blood pressure is much higher in pheochromocytoma than in 
non-pheochromocytoma patients (Hsu et al. 1993). This apparent discrepancy may be explained by differences in the functional properties of 5- $\mathrm{HT}_{4}$ receptors respectively expressed by the normal adrenal medulla and pheochromocytoma tissues. Indeed, although real-time RT-PCR experiments using primers specific to the common region of all $5-\mathrm{HT}_{4}$ receptor variants had shown that the normal adrenal medulla actually expresses the receptor, no specific cDNA band could be detected after RT-PCR amplification of mRNAs encoding the currently known isoforms of the $5-\mathrm{HT}_{4}$ receptor in medulla extracts. These results show that adrenomedullary cells express $5-\mathrm{HT}_{4}$ receptor isoforms different from the already-recognized splicing variants. It is conceivable that these unidentified isoforms may be less efficiently activated by metoclopramide than the variants that were detected in pheochromocytomas explants. In addition, recent studies have shown that 5- $\mathrm{HT}_{4}$ receptors, like other G-proteincoupled receptors, can form homo- and/or heterodimers that modulate receptor function (Berthouze et al. 2005). It is thus possible that differences in the expression profiles of $5-\mathrm{HT}_{4}$ receptor splice variants among tissues could lead to a weak responsiveness to metoclopramide in normal adrenal medulla in comparison with pheochromocytomas. Conversely, we cannot exclude that metoclopramide stimulates catecholamine secretion from the normal adrenal medulla as efficiently as it does in pheochromocytoma tissues but the low mass of catecholamine-secreting tissue in non-pheochromocytoma patients prevents them from experiencing metoclopramide-evoked hypertension crisis.

The different patterns of expression of $5-\mathrm{HT}_{4}$ receptor isoforms observed respectively in the normal adrenal medulla and pheochromocytoma tissues also suggest that maturation of $5-\mathrm{HT}_{4}$ receptor primary transcripts is altered in adrenomedullary tumors in comparison with normal adrenal chromaffin tissue. Nevertheless, processing of the $5-H T_{4}$ receptor mRNA does not seem to depend on the degree of differentiation of tumors since expression profiles of $5-\mathrm{HT}_{4}$ receptor isoforms were not significantly different in benign versus malignant tumors.

Pheochromocytoma crisis is a rare life-threatening emergency, with a high mortality rate, i.e., reaching $85 \%$ in some studies (Brouwers et al. 2003). Preventing paroxysmal crises and their potentially life-threatening consequences, such as acute heart failure and seizures, is a major goal of the preoperative management of patients with pheochromocytoma. On the other hand, it is well known that hypertensive episodes may be precipitated by various drugs that potentiate the action of catecholamines or directly stimulate pheochromocytoma tissues and are therefore contraindicated in patients with pheochromocytoma (Keiser 2001, Eisenhofer et al. 2007). However, drug-induced paroxysms are often unpredictable with new compounds whose action on adrenomedullary cells is generally unknown. In this respect, several new potent $5-\mathrm{HT}_{4}$ receptor agonists, like tegaserod, mosapride, and prucalopride, are currently developed or have already been commercialized in several countries as digestive tract prokinetic agents. Since decreased gastrointestinal motility is one of the non-specific features of pheochromocytoma (Keiser 2001), some patients with unrecognized pheochromocytoma may potentially be treated with these compounds. Although $5-\mathrm{HT}_{4}$ receptor agonistevoked hypertension crisis has not yet been reported, the present study, which shows that adrenomedullary tumors express functional 5- $\mathrm{HT}_{4}$ receptors, suggests that administration of these prokinetic agents to pheochromocytoma patients would lead to a high risk of paroxysmal crisis. This assumption is supported by the observation that the expression rates of the $5-\mathrm{HT}_{4}$ receptor in pheochromocytoma tissues were similar to or higher than those previously noted in the gastrointestinal tract and adrenal cortex, two organs that are well known to respond in vivo to the stimulatory action of 5- $\mathrm{HT}_{4}$ receptor agonists (Cartier et al. 2005, van Lelyveld et al. 2007). It seems therefore reasonable to recommend to systematically eliminate the diagnosis of pheochromocytoma by the use of urinary or plasma metanephrine measurements before prescribing $5-\mathrm{HT}_{4}$ receptor agonists when decreased gastrointestinal motility is associated with hypertension and/or signs of catecholamine excess.

In summary, the present in vitro study shows that metoclopramide stimulates catecholamine- and graninderived peptide secretions from pheochromocytoma tissue by activating serotonin $5-\mathrm{HT}_{4}$ receptors rather than antagonizing $\mathrm{D}_{2}$ receptors. Our data also suggest that all $5-\mathrm{HT}_{4}$ receptor agonists, including the newly developed compounds tegaserod, mosapride, and prucalopride, might better be avoided in patients with proven or suspected pheochromocytoma.

\section{Declaration of interest}

All authors have nothing to disclose.

\section{Funding}

This work was supported by the Conseil Régional de HauteNormandie, IFRMP 23, INSERM U413, the Centre Hospitalier Universitaire de Rouen, and the Réseau COMETE (PHRC AOM 02068). 


\section{Acknowledgements}

The authors thank Dr Claudia Cavadas and Joana Rosmaninho-Salgado for providing normal human adrenal medulla mRNA.

\section{References}

Abe M, Orita Y, Nakashima Y \& Nakamura M 1984 Hypertensive crisis induced by metoclopramide in patient with pheochromocytoma. Angiology 35 122-128.

Adler-Graschinsky E, Rubio MC \& Barontini De Moyano M 1984 Metoclopramide increases the release of catecholamines from isolated human phaeochromocytomas. Journal of Hypertension 2 127-129.

Agabiti-Rosei E, Alicandria CL \& Corea L 1977 Hypertensive crisis in patients with phaeochromocytoma given metoclopramide. Lancet 1600.

Berthouze M, Ayoub M, Russo O, Rivail L, Sicsic S, Fischmeister R, Berque-Bestel I, Jockers R \& Lezoualc'h F 2005 Constitutive dimerization of human serotonin 5-HT4 receptors in living cells. FEBS Letters 579 2973-2980.

Bockaert J, Claeysen S, Compan V \& Dumuis A 2004 5-HT4 receptors. Current Drug Targets. CNS and Neurological Disorders 3 39-51.

Brattelid T, Kvingedal AM, Krobert KA, Andressen KW, Bach T, Hystad ME, Kaumann AJ \& Levy FO 2004 Cloning, pharmacological characterisation and tissue distribution of a novel 5-HT4 receptor splice variant, 5-HT4(i). Naunyn-Schmiedeberg's Archives of Pharmacology 369 616-628.

Brouwers FM, Lenders JW, Eisenhofer G \& Pacak K 2003 Pheochromocytoma as an endocrine emergency. Reviews in Endocrine and Metabolic Disorders 4 121-128.

Cartier D, Lihrmann I, Parmentier F, Bastard C, Bertherat J, Caron P, Kuhn JM, Lacroix A, Tabarin A, Young J et al. 2003 Overexpression of serotonin4 receptors in cisaprideresponsive adrenocorticotropin-independent bilateral macronodular hyperplasia causing Cushing's syndrome. Journal of Clinical Endocrinology and Metabolism $\mathbf{8 8}$ 248-254.

Cartier D, Jegou S, Parmentier F, Lihrmann I, Louiset E, Kuhn JM, Bastard C, Plouin PF, Godin M, Vaudry H et al. 2005 Expression profile of serotonin4 (5-HT4) receptors in adrenocortical aldosterone-producing adenomas. European Journal of Endocrinology 153 939-947.

Cavadas C, Silva AP, Mosimann F, Cotrim MD, Ribeiro CA, Brunner HR \& Grouzmann E 2001 NPY regulates catecholamine secretion from human adrenal chromaffin cells. Journal of Clinical Endocrinology and Metabolism 86 5956-5963.

Christopoulos S, Bourdeau I \& Lacroix A 2005 Clinical and subclinical ACTH-independent macronodular adrenal hyperplasia and aberrant hormone receptors. Hormone Research 64 119-131.
Crivellato E, Nico B, Ribatti D \& Nussdorfer GG 2006 Catecholamine release by chromaffin cells: a lesson from mast cells. General and Comparative Endocrinology 146 69-73.

Dumuis A, Sebben M \& Bockaert J 1989 The gastrointestinal prokinetic benzamide derivatives are agonists at the nonclassical 5-HT receptor (5-HT4) positively coupled to adenylate cyclase in neurons. Naunyn-Schmiedeberg's Archives of Pharmacology 340 403-410.

Eisenhofer G, Rivers G, Rosas AL, Quezado Z, Manger WM \& Pacak K 2007 Adverse drug reactions in patients with phaeochromocytoma: incidence, prevention and management. Drug Safety 30 1031-1062.

Fink L, Seeger W, Ermert L, Hänze J, Stahl U, Grimminger F, Kummer W \& Bohle RM 1998 Real-time quantitative RT-PCR after laser-assisted cell picking. Nature Medicine 4 1329-1333.

Fraser R 1987 Dopamine regulation of aldosterone secretion: an open question? Journal of Endocrinology 112 179-181.

Gross AS, Goh YD, Addison RS \& Shenfield GM 1999 Influence of grapefruit juice on cisapride pharmacokinetics. Clinical Pharmacology and Therapeutics 65 395-401.

Grossman CJ, Kilpatrick GJ \& Bunce KT 1993 Development of a radioligand binding assay for 5-HT4 receptors in guinea-pig and rat brain. British Journal of Pharmacology 109 618-624.

Guillemot J, Anouar Y, Montero-Hadjadje M, Grouzmann E, Grumolato L, Roshmaninho-Salgado J, Turquier V, Duparc C, Lefebvre H, Plouin PF et al. 2006 Circulating EM66 is a highly sensitive marker for the diagnosis and follow-up of pheochromocytoma. International Journal of Cancer 118 2003-2012.

Harrington RA, Hamilton CW, Brogden RN, Linkewich JA, Romankiewicz JA \& Heel RC 1983 Metoclopramide. An updated review of its pharmacological properties and clinical use. Drugs 25 451-494.

Hsu TS, Lee CP \& Kuo CT 1993 Diagnostic use of metoclopramide in hypertension caused by pheochromocytoma. International Journal of Cardiology 42 79-86.

Joannides R, Moore N, Iacob M, Compagnon P, Bacri AM \& Thuillez C 1998 Divergent effects of verapamil and amlodipine at rest and during exercise. Journal of Hypertension 16 S25-S29.

Keiser HR 2001, Pheochromocytoma and related tumors. In Endocrinology, vol3, edn 4, pp 1862-1883. Eds LJ DeGroot \& LJ Jameson. Philadelphia: WB Saunders Company.

Lamparczyk H, Chmielewska A, Konieczna L, Plenis A \& Zarzycki PK 2001 RP-HPLC method with electrochemical detection for the determination of metoclopramide in serum and its use in pharmacokinetic studies. Biomedical Chromatography 15 513-517.

Lefebvre H, Contesse V, Delarue C, Soubrane C, Legrand A, Kuhn JM, Wolf LM \& Vaudry H 1993 Effect of the serotonin-4 receptor agonist zacopride on aldosterone 
secretion from the human adrenal cortex. In vivo and in vitro studies. Journal of Clinical Endocrinology and Metabolism 77 1662-1666.

van Lelyveld N, Ter Linde J, Schipper ME \& Samsom M 2007 Regional differences in expression of TPH-1, SERT, 5-HT(3) and 5-HT(4) receptors in the human stomach and duodenum. Neurogastroenterology and Motility 19 342-348.

Leow MK \& Loh KC 2005 Accidental provocation of phaeochromocytoma: the forgotten hazard of metoclopramide? Singapore Medical Journal 46 557-560.

Mannelli M, Pupilli C, Lanzillotti R, Ianni L, Bellini F \& Sergio M 1995 Role for endogenous dopamine in modulating sympathetic-adrenal activity in humans. Hypertension Research 18 S79-S86.

Maxwell PH, Buckley C, Gleadle JM \& Mason PD 2001 Nasty shock after an anti-emetic. Nephrology, Dialysis, Transplantation 16 1069-1072.

Molitch ME 1992 Pathologic hyperprolactinemia. Endocrinology and Metabolism Clinics of North America 21 877-901.

Montero-Hadjadje M, Vaudry H, Turquier V, Leprince J, Do Rego JL, Yon L, Gallot-Payet N, Plouin PF \& Anouar Y 2002 Localization and characterization of evolutionarily conserved chromogranin A-derived peptides in the rat and human pituitary and adrenal glands. Cell and Tissue Research 310 223-236.
Norbiato G, Bevilacqua M, Raggi U, Micossi P \& Moroni C 1977 Metoclopramide increases plasma aldosterone concentration in man. Journal of Clinical Endocrinology and Metabolism 45 1313-1316.

Plouin PF, Menard J \& Corvol P 1976 Hypertensive crisis in patient with phaeochromocytoma given metoclopramide. Lancet 2 1357-1358.

Rizzi CA, Mierau J \& Ladinsky H 1997 Regulation of plasma aldosterone levels by metoclopramide: a reappraisal of its mechanism from dopaminergic antagonism to serotonergic agonism. Neuropharmacology 36 763-768.

Sever PS 1977 Hypertensive crisis in patients with phaeochromocytoma given metoclopramide. Lancet 1703.

Wu KD, Chen YM, Chu TS, Chueh SC, Wu MH \& Bor-Shen H 2001 Expression and localization of human dopamine D2 and D4 receptor mRNA in the adrenal gland, aldosterone-producing adenoma, and pheochromocytoma. Journal of Clinical Endocrinology and Metabolism 86 4460-4467.

Yon L, Guillemot J, Montero-Hadjadje M, Grumolato L, Leprince J, Lefebvre H, Contesse V, Plouin PF, Vaudry H \& Anouar Y 2003 Identification of the secretogranin II-derived peptide EM66 in pheochromocytomas as a potential marker for discriminating benign versus malignant tumors. Journal of Clinical Endocrinology and Metabolism 88 2579-2585. 